\title{
Adaptation of the single-cone in prepared long oval-shaped canals: a micro-
}

\section{computed tomography study}

\author{
Adaptação de cone único no preparo de canais ovais-longos: estudo em micro-CT \\ Adaptación de un solo cono en la preparación de conductos ovalados largos: un estudio de micro-CT
}

Christianne Velozo

ORCID: https://orcid.org/0000-0001-9651-3043 Universidade de Pernambuco, Brazil

E-mail: chris_velozo@hotmail.com

Hugo Dantas

ORCID: https://orcid.org/0000-0002-3931-0802 Universidade Federal da Paraíba, Brazil

E-mail: hugodantas92@gmail.com

Basílio Rodrigues Vieira

ORCID: https://orcid.org/0000-0002-2025-7773 Universidade Federal da Paraíba, Brazil

E-mail:basilio_451@hotmail.com

Frederico Barbosa de Sousa

ORCID: https://orcid.org/0000-0002-9158-8342

Universidade Federal da Paraíba, Brazil E-mail: fredericosousa@hotmail.com

Victor Felipe Farias do Prado

ORCID: https://orcid.org/0000-0002-9790-8001

Universidade de Pernambuco, Brazil E-mail: victor.prado@upe.br

Ismael Sebastião da Silva Sousa

ORCID: https://orcid.org/0000-0002-7947-8933 Universidade de Pernambuco, Brazil E-mail: ismael.sousa @upe.br

Maria Beatriz Arruda Albuquerque ORCID: https://orcid.org/0000-0002-4955-4851 Universidade de Pernambuco, Brazil E-mail: beatriz.arrudaa@upe.br

Diana Santana de Albuquerque ORCID: https://orcid.org/0000-0002-7897-2489 Universidade de Pernambuco, Brazil E-mail: dianaendodontia@gmail.com

\begin{abstract}
The present study aimed to evaluate adaptation of the single gutta-percha cone on root canal walls prepared with the two systems, the XP-endo Shaper (XPS; FKG Dentaire, La Chaux-de-Fonds, Switzerland) and ProTaper Next systems (PTN; Dentsply Sirona, Ballaigues, Switzerland) by using micro-computed tomography (micro-CT) technology. Twenty long oval-shaped canals in mandibular incisors were scanned by micro-CT (Skyscan 1172; Bruker microCT, Kontich, Belgium). Two groups were divided into $(n=10)$ according to the canal preparation protocol: XPS group with an extra $45 \mathrm{~s}$ of instrumentation and PTN group. A gutta percha cone, with respect to the protocol used for each group (size 40, .04 taper, XPS and size 40, .06 taper, PTN) was adapted to the canal at the working length of all the samples, and all root canals were filled, using the single-cone technique. The mean values for volume of voids and percentage relative to the mentioned space were correspondingly higher in XPS group than they were PTN group, mean values for volume of voids $(3.61 \mathrm{~mm} 3-1.92 \mathrm{~mm} 3)$ and for percentage of voids $(39.25 \%-23.28 \%)$, respectively, significant differences were recorded $(\mathrm{p}<0.05)$ between the two groups (XPS and PTN, Student's-t test for homogenous variances and Mann-Whitney test). The canals prepared with XPS, in the procedure performed with an extra $45 \mathrm{~s}$ of instrumentation, showed a higher volume of voids than those prepared with the PTN system, in obturation of the root canal with the single cone technique.
\end{abstract}

Keywords: Micro-CT; Protaper Next; Root canal preparation; Single-cone; Xp-endo shaper. 


\begin{abstract}
Resumo
O presente estudo teve como objetivo avaliar a adaptação do cone único de guta-percha nas paredes do canal radicular preparadas com os dois sistemas, o XP-endo Shaper (XPS; FKG Dentaire, La Chaux-de-Fonds, Suíça) e o sistema ProTaper Next (PTN ; Dentsply Sirona, Ballaigues, Suíça) usando tecnologia de micro tomografia computadorizada (micro-CT). Vinte longos canais ovais em incisivos inferiores foram examinados por micro-TC (Skyscan 1172; Bruker microCT, Kontich, Bélgica). Dois grupos foram divididos em $(\mathrm{n}=10)$ de acordo com o protocolo de preparo do canal: grupo XPS com 45 segundos extras de instrumentação e grupo PTN. Um cone de guta-percha, no que diz respeito ao protocolo usado para cada grupo (tamanho 40, cone 0,04, XPS e tamanho 40, cone 0,06, PTN) foi adaptado ao canal no comprimento de trabalho de todas as amostras, e todas as raízes os canais foram preenchidas pela técnica de cone único. Os valores médios para o volume de vazios e porcentagem em relação ao espaço mencionado foram correspondentemente maiores no grupo XPS do que no grupo PTN, valores médios para o volume de vazios $(3,61 \mathrm{~mm} 3$ - 1,92 mm3) e para a porcentagem de vazios $(39,25 \%$ - 23,28\% ), respectivamente, diferenças significativas foram registradas $(\mathrm{p}<0,05)$ entre os dois grupos (XPS e PTN, teste t de Student para variâncias homogêneas e teste de MannWhitney). Os canais preparados com XPS, no procedimento realizado com 45 s extras de instrumentação, apresentaram maior volume de vazios do que os preparados com sistema PTN, na obturação do canal radicular com a técnica de cone único.
\end{abstract}

Palavras-chave: Micro-CT; Protaper Next; Preparo do canal radicular; Cone único; Xp-endo Shaper.

\title{
Resumen
}

El presente estudio tuvo como objetivo evaluar la adaptación del cono único de gutapercha en las paredes del conducto radicular preparado con los dos sistemas, el XP-endo Shaper (XPS; FKG Dentaire, La Chaux-de-Fonds, Suiza) y los sistemas ProTaper Next (PTN). Dentsply Sirona, Ballaigues, Suiza) mediante el uso de tecnología de micro tomografía computarizada (micro-CT). Se escanearon 20 conductos largos de forma ovalada en los incisivos mandibulares mediante micro-CT (Skyscan 1172; Bruker microCT, Kontich, Bélgica). Se dividieron dos grupos en $(\mathrm{n}=10)$ de acuerdo con el protocolo de preparación del canal: grupo XPS con $45 \mathrm{~s}$ adicionales de instrumentación y grupo PTN. Un cono de gutapercha, con respecto al protocolo utilizado para cada grupo (tamaño 40, cono .04, XPS y tamaño 40, cono .06, PTN) se adaptó al conducto a la longitud de trabajo de todas las muestras y todas las raíces. Los canales se rellenaron mediante la técnica de un solo cono. Los valores medios para el volumen de huecos y el porcentaje relativo al espacio mencionado fueron correspondientemente más altos en el grupo XPS que en el grupo PTN, los valores medios para el volumen de huecos $(3,61 \mathrm{~mm} 3$ - 1,92 mm3) y para el porcentaje de huecos $(39,25 \%$ - 23,28\%), respectivamente, se registraron diferencias significativas ( $\mathrm{p}<0,05)$ entre los dos grupos (XPS y PTN, prueba t de Student para varianzas homogéneas y prueba de Mann-Whitney). Los conductos preparados con XPS, en el procedimiento realizado con $45 \mathrm{~s}$ extra de instrumentación, mostraron un mayor volumen de vacíos que los preparados con el sistema PTN, en la obturación del conducto radicular con la técnica de cono único.

Palabras clave: Micro-CT; Protaper Next; Preparación del conducto radicular; Solo cono; XP-endo Shaper.

\section{Introduction}

A successful endodontic treatment depends on appropriate access cavity preparation, shaping, cleaning/disinfection, and three-dimensional filling of the root canal space (Haapasalo et al., 2005). It is well known that cleaning/disinfection procedures do not eradicate $100 \%$ of bacteria in an infected root canal system (Park et al., 2012). Therefore, the aim of obturation is to entomb the residual bacteria and their by-products (Sundqvist et al., 1998). The incidence of voids in root canal obturation has been reported, especially in oval or irregular root canals (Keleş et al., 2014). This may result in proliferation of residual bacteria that may jeopardize the long-term outcome (Keleş et al., 2014 ; Kontakiotis et al., 1997).

The ProTaper Next system (PTN) (Mohammadi et al., 2009) with its asymmetrical rectangular cross-section and the XP-endo Shaper system (XPS) (FKG Dentaire. 2021), which expands beyond the size of its core at temperatures of $35^{\circ} \mathrm{C}$ or higher. These systems can be especially recommended for canals with irregular geometries, because, in addition to enabling more conservative preparations, it simultaneously promotes a greater contact surface of the instrument with the canal walls (Gavini et al., 2018).

The single-cone technique is an easy and low-cost method (Heran et al., 2019 Keleş et al., 2020) that uses one guttapercha cone with the same size and taper that of the root canal preparation (Wang et al 2018), and has demonstrated filling capacity in circular root canals (Somma et al., 2011). However, in long oval root canals, this obturation technique can be a challenge. Therefore, the aim of the present study was to evaluate the adaptation of the single guta-percha cone on the walls of 
the canal prepared with the two systems with an off-centered rotation axis, XPS and PTN, in long oval shaped root canals of mandibular incisors, by using micro-CT imaging technology. The null hypothesis was that there would be no difference in adaptation of the gutta-percha cones between the two systems.

\section{Methodology}

\section{Specimen selection and groups}

After local ethics committee approval (approval number: 3.201.839), 47 straight, single-rooted human mandibular incisors without caries and with fully formed root apices were randomly selected from a pool of extracted teeth. The sample size estimated with MINITAB 17.1 was 10 samples per group. Individual scanning of the samples was performed with the SkyScan 1172 micro-CT device (Bruker micro-CT, Kontich, Belgium). Each tooth was placed on the rotating platform with the root facing upwards. The following parameters were used: voltage of $100 \mathrm{kV}$, current of $100 \mathrm{~mA}$, resolution of $26.8 \mu \mathrm{m}$, rotation of $360^{\circ}$, a copper + aluminium filter, rotation step of 0.6 , and the total scanning time for $1 \mathrm{~h}$ and $24 \mathrm{~min}$. After digitalization, the images were reconstructed and converted to bitmap images using the NRecon software (Bruker micro-CT), which produced 600-700 images per tooth using the following parameters: smoothing of 5, ring artefact correction of 6 and beam hardening correction of $25 \%$. The images were aligned with the Data Viewer software (Bruker micro-CT) for morphometric analysis. Preoperative threedimensional (3D) models of the root canals were processed for evaluating the canal configuration. The 3D parameters of the root canals were calculated as previously described (Versiani et al., 2013) using the CT-Analyzer v.1.13 software (Bruker micro-CT). The 3D measurements (root canal lenght, volume, surface area) were based on a volume model of the root canal in 3D extending from the level of the cementoenamel junction on the buccal side of the root to the apex. The canal was defined as a long ovalshaped canal when the ratio between the major and minor canal diameters was $>2$ (i.e., when one dimension was at least two times that of a measurement made at right angles) and $<4$ (Wu et al., 2000 ; Jou et al., 2004). One tooth of each group was then randomly attributed (www.random.org) to one of the two experimental groups $(n=10)$ according to the canal preparation protocol: XPS and PTN. After verification of the normality assumption (Shapiro-Wilk test) and homogeneity of variance (Levene's F test), of the two groups with respect to the 3D root canal (length, volume, surface area) morphometric parameters were statistically confirmed at a significance level of $5 \%$ (Table 1).

\section{Root canal preparation}

The canals were explored, and patency was confirmed with a size $10 \mathrm{~K}$-file (Dentsply Sirona, Ballaigues, Switzerland) when the teeth were held in the hand, when the tip of the instrument was visible close to the apical foramen. The working length (WL) was established at $0.5 \mathrm{~mm}$ short of the foramen. The glide path was obtained until a size $15 \mathrm{~K}$-file (Dentsply Sirona). In group $1(n=10)$, the tip of the XPS instrument was inserted into the canal, and the instrument was activated in the rotation mode (Xsmart plus motor, Dentsply; $800 \mathrm{rpm}$ and $1.0 \mathrm{Ncm}$ ). 5 gentle up-and-down movements were applied until the WL was reached. Once the instrument reached the WL, another 10 up-and-down movements were performed. Each specimen was then submitted to an extra $45 \mathrm{~s}$ of active instrumentation with XPS at WL, extrapolating the recommendation of the manufacturer (De-Deus et al., 2019 ; Velozo et al., 2020). To confirm the end of root canal shaping, a gutta-percha cone with a size 40, .04 taper (Endo Tanare plus) was matched to the WL. If the cone did not fit, 3-5 up-and-down movements were performed with the instrument up to the WL, as well as soft buccal and lingual brush strokes. In group $2(n=10)$, the PTN instrument was activated in rotation mode (Xsmart plus motor, Dentsply; $300 \mathrm{rpm}$ and $2.0 \mathrm{Ncm}$ ). The preparation protocol was repeated throughout the entire length of the canal according to manufacturer instructions until the WL was reached. Three up-and-down movements and 2 soft brush strokes were applied to each buccal and lingual wall. To confirm the end of canal instrumentation, a size 40, .06 taper guttapercha cone (PTN; X4, Dentsply Sirona, Pirassununga, Sao Paulo, Brazil) was matched to the WL Irrigation was performed 
throughout the preparation procedure with a total of $18 \mathrm{~mL}$ of a preheated $2.5 \%$ sodium hypochlorite solution $\left(38^{\circ} \mathrm{C} \pm 1^{\circ} \mathrm{C}\right)$ delivered using a 30-G NaviTip needle (Ultradent, South Jordan, UT) adapted to a disposable plastic syringe placed up to $2 \mathrm{~mm}$ short of the WL.

\section{Micro-CT Analysis}

Postoperative models of the canals were obtained with the CT-Analyzer v.1.13 software. After scanning by micro-CT for analysis of the post-preparation (Post1) condition, a gutta percha cone with respect to the protocol used for each group (size 40, .04 taper, XPS and size 40, .06 taper, PTN) was adapted to each canal at the working length of all the samples, and adaptation of the gutta-percha cones was observed radiographically. All root canals were filled using the single-cone technique without sealer. The samples were then submitted to a new post-obturation (Post 2), and reconstruction scanning procedure, by applying the initial configurations of the micro-CT parameters previously mentioned. These data were co-registered with their respective Post1 data sets using the Data Viewer software (Bruker micro-CT). A qualitative comparison between groups was performed using color-coded models of the corresponding root canals, where green and orange indicated volume, Post1 and Post2, respectively. The CTVol v.2.0 software (Bruker micro-CT) was used for this analysis. The postoperative parameters (volume, area of the root canal surface) were acquired with the CTAn v.1.13 software. To obtain the percentage of voids, the postpreparation volume of the canal and volume of filling material used were considered, by using the following formula: [Percentage of voids $=100-($ filling material volume $\times 100 /$ canal volume) (Tavares et al., 2021). Representative images were captured using CTVol v.2.0 software (Bruker microCT).

\section{Statistical analysis}

To evaluate significant difference between the two Groups, the Student's-t test for two independent samples with equal variances was used, or the Mann-Whitney test. The student's-t test for independent samples was chosen in situations in which the normality of the data was verified, whereas the Mann-Whitney test was used in situations when normality was rejected. Normality was verified by the Shapiro Wilk test, and equality of variances, by means of the Levene F test, The margin of error used in the statistical tests was 5\%. The SPSS software (Version 23; IBM SPSS, Inc., Chicago, IL, USA) was used for all statistical analyses.

\section{Results}

Table 1 shows the results of the 3D parameters (canal length, volume, surface area) and aspect ratio in the root canal of 20 mandibular incisors before and after preparation with the different systems (XPS and PTN). In general, the preparation protocols significantly increased all parameters analysed in each group $(\mathrm{P}<0.05)$. The mean percentage increase of volume was similar in the XPS and PTN groups (107.5\% and 93.13\%, respectively; $\mathrm{P}>0.05)$. The mean percentage increase of surface area was $27.74 \%$ in the XPS group and $29.68 \%$ in the PTN group (P > 0.05). 
Table 1. Parameters and \% increase before and after preparation of 20 mandibular incisors with long oval-shaped canals with the XP-endo Shaper and ProTaper Next systems.

\begin{tabular}{|c|c|c|c|c|}
\hline Parameters & & $\begin{array}{c}\text { Group 1 } \\
\text { XP-endo Shaper } \\
(\mathbf{n}=\mathbf{1 0}) \\
\text { Mean } \pm \text { SD } \\
\text { Median (P25; P75) }\end{array}$ & $\begin{array}{c}\text { Group 2 } \\
\text { ProTaper Next X4 } \\
(\mathbf{n}=\mathbf{1 0}) \\
\text { Mean } \pm \text { SD } \\
\text { Median }(\mathrm{P} 25 ; \mathrm{P} 75)\end{array}$ & $P$ value \\
\hline \multicolumn{2}{|l|}{ Length } & $\begin{array}{c}11.94 \pm 1.07 \\
11.61(11.10 ; 13.00)\end{array}$ & $\begin{array}{c}12.06 \pm 1.66 \\
12.18(11.08 ; 13.79)\end{array}$ & $\mathrm{p}(1)=0.848$ \\
\hline \multicolumn{2}{|l|}{ Aspect ratio } & $\begin{array}{c}2.17 \pm 0.56 \\
2.40(1.68 ; 2.60)\end{array}$ & $\begin{array}{c}2.08 \pm 0.88 \\
1.91(1.34 ; 2.73)\end{array}$ & $\mathrm{p}(1)=0.800$ \\
\hline \multirow[t]{3}{*}{ Volume } & Before & $\begin{array}{c}5.91 \pm 2.76 \\
5.35(3.95 ; 9.06)\end{array}$ & $\begin{array}{c}5.36 \pm 2.35 \\
4.43(3.46 ; 7.24)\end{array}$ & $\mathrm{p}(2)=0.481$ \\
\hline & After & $\begin{array}{c}10.63 \pm 2.50 \\
10.34(9.20 ; 12.70)\end{array}$ & $\begin{array}{c}9.63 \pm 2.47 \\
9.21(7.55 ; 11.66)\end{array}$ & $\mathrm{p}(1)=0.381$ \\
\hline & Increase (\%) & $\begin{array}{c}107.50 \pm 78.05 \\
79.92(55.61 ; 146.46)\end{array}$ & $\begin{array}{c}93.13 \pm 47.51 \\
92.27(47.13 ; 121.78)\end{array}$ & $\mathrm{p}(1)=0.625$ \\
\hline \multirow[t]{3}{*}{ Surface area } & Before & $\begin{array}{c}37.07 \pm 9.57 \\
35.89(31.37 ; 46.32)\end{array}$ & $\begin{array}{c}34.65 \pm 9.11 \\
33.97(25.55 ; 40.09)\end{array}$ & $p(1)=0.570$ \\
\hline & After & $\begin{array}{c}46.05 \pm 7.93 \\
45.08(41.49 ; 51.65)\end{array}$ & $\begin{array}{c}44.23 \pm 9.12 \\
43.49(36.97 ; 53.26)\end{array}$ & $\mathrm{p}(1)=0.639$ \\
\hline & Increase (\%) & $\begin{array}{c}27.74 \pm 17.95 \\
21.24(16.32 ; 35.47)\end{array}$ & $\begin{array}{c}29.68 \pm 13.14 \\
25.50(18.29 ; 41.40)\end{array}$ & $\mathrm{p}(2)=0.436$ \\
\hline
\end{tabular}

Results are reported as the mean, standard deviation (SD), median, and $25^{\text {th }}$ and 75 percentiles (P25; P75). SMI: structure model index.

(1) Student t-test for homogenous variances, $p>.05$. (2) Mann-Whitney test, $p>.05$. Source: Authors.

Table 2 shows the results of the 3D parameters (post-preparation volume of the canal, volume of the gutta-percha cone, volume of the voids, area of the gutta percha cone surface, and area of the voids surface) and percentage of the gutta percha cone and voids, according to each of the Groups. The measurement of the post-preparation canal volume was correspondingly higher in the XPS Group than it was in the PTN (the measurements of post-preparation volume were $8.69 \mathrm{~mm} 3 \mathrm{and} 7.96 \mathrm{~mm} 3$, respectively). The measurements of the gutta percha cone and of its percentages were correspondingly higher in the PTN Group than in the XPS Group (mean values of gutta percha cone volume were $6.04 \mathrm{~mm} 3$ and $5.08 \mathrm{~mm} 3$ and the corresponding measurements of percentage were: $76.72 \%$ and $60.75 \%$ ) respectively. The mean values for volume of voids and percentage relative to the mentioned voids were correspondingly higher in XPS (mean values for volume of voids (3.61 mm3 - $1.92 \mathrm{~mm} 3)$ and mean values for percentage of voids $(39.25 \%-23.28 \%)$, respectively. For the level of significance considered $(5 \%)$ significant differences were recorded $(\mathrm{p}<0.05)$ between the two groups in the following variables: volume of voids, percentage of gutta percha cone, percentage of voids and area of voids surface. 
Table 2 Statistics of 3D variables: post- volume of canal, volume of obturating material, volume of void, area of obturating material surface, area of voids space surface, percentage of obturating material and percentage of voids, according to each group.

\begin{tabular}{|c|c|c|c|}
\hline Variable & $\begin{array}{c}\text { Group 1 } \\
\text { XP-endo Shaper } \\
\end{array}$ & $\begin{array}{r}\text { Group 2 } \\
\text { Protaper Next X4 } \\
\end{array}$ & p-value \\
\hline Post- Volume of Canal & $\begin{array}{c}8.69 \pm 2.36 \\
8.32(7.22 ; 11.36)\end{array}$ & $\begin{array}{c}7.96 \pm 2.06 \\
7.78(6.74 ; 8.80)\end{array}$ & $\mathrm{p}^{(1)}=0.475$ \\
\hline Volume of gutta percha $\left(\mathrm{mm}^{3}\right)$ & $\begin{array}{c}5.08 \pm 0.90 \\
4.76(4.41 ; 6.01)\end{array}$ & $\begin{array}{c}6.04 \pm 1.42 \\
6.15(4.85 ; 7.11)\end{array}$ & $\mathrm{p}^{(1)}=0.088$ \\
\hline Volume of voids $\left(\mathrm{mm}^{3}\right)$ & $\begin{array}{c}3.61 \pm 1.79 \\
3.14(2.45 ; 5.57)\end{array}$ & $\begin{array}{c}1.92 \pm 1.21 \\
1.34(1.15 ; 2.60)\end{array}$ & $\mathrm{p}^{(2)}=0.035^{*}$ \\
\hline Percentage of gutta percha $(\%)^{(3)}$ & $\begin{array}{c}60.75 \pm 12.72 \\
58.61(52.64 ; 66.37)\end{array}$ & $\begin{array}{c}76.72 \pm 9.91 \\
78.83(66.54 ; 84.71)\end{array}$ & $\mathrm{p}^{(1)}=0.006^{*}$ \\
\hline Percentage of voids $(\%)^{(3)}$ & $\begin{array}{c}39.25 \pm 12.72 \\
41.39(33.63 ; 47.36)\end{array}$ & $\begin{array}{c}23.28 \pm 9.91 \\
21.17(15.29 ; 33.46)\end{array}$ & $\mathrm{p}^{(1)}=0.006^{*}$ \\
\hline Area of gutta percha surface $(\mathrm{mm} 2)$ & $\begin{array}{c}30.24 \pm 4.34 \\
28.20(27.43 ; 34.45)\end{array}$ & $\begin{array}{c}32.72 \pm 5.78 \\
33.17(28.04 ; 36.66)\end{array}$ & $\mathrm{p}^{(1)}=0.293$ \\
\hline Area of void surface (mm2) & $\begin{array}{c}39.26 \pm 13.98 \\
37.39(33.54 ; 49.13)\end{array}$ & $\begin{array}{c}24.09 \pm 8.43 \\
20.64(17.28 ; 30.37)\end{array}$ & $\mathrm{p}^{(1)}=0.009^{*}$ \\
\hline
\end{tabular}

(*) Significant Difference at level of 5.0\% (1) By the Student's- $t$ test with equal variances (2) By the Mann-Whitney test Source: Authors.

Qualitative evaluation, displayed as superimposition of postoperative1 (post1, without gutta-percha cone, green) and postoperative 2 (post2, with gutta-percha cone, orange) areas, showed maintenance of voids in all groups (Figure 1).

Figure 1 Qualitative evaluation, displayed as superimposition of postoperative1 (post1) and postoperative 2 (post2) areas, showed maintenance of voids in all groups.

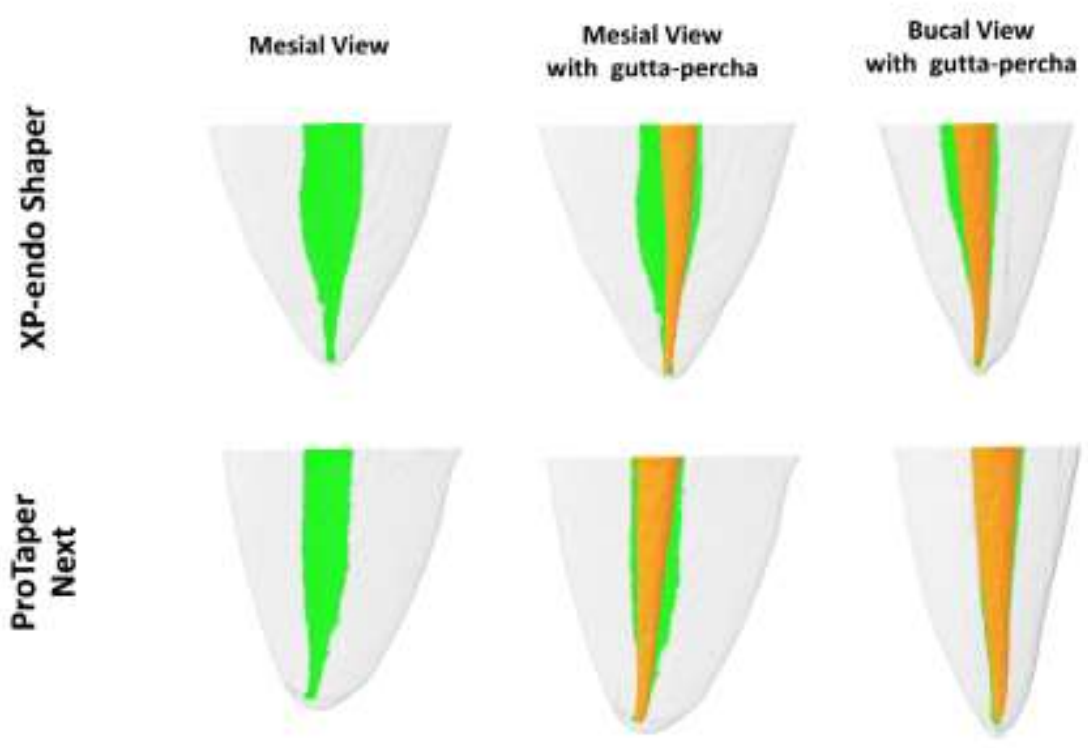

Source: Authors.

\section{Discussion}

The occurrence of voids in root canal obturation in long-oval root canals become the single-cone technique a challenge. This study evaluate the adaptation of the single guta-percha cone of the canal prepared with the XP-endo Shaper and ProTaper Next. This is the first study that has used the single-cone technique to evaluate the adaptation of the gutta-percha cone to the 
walls of oval long root canal and the to obtain the percentage of voids, without the use of endodontic cement, for better analysis of void spaces using micro-CT technology. The quality of the filling is influenced by root canal morphology and root canals with a large buccolingual extension are more difficult to fill (De-Deus et al., 2008; Pereira et al., 2017). The protocol used in the present study used an extra $45 \mathrm{~s}$ of instrumentation when the XP-endo Shaper was used, which resulted in a more complete root canal preparation and a consequent increase in den- tine removal, as also demonstrated in other studies (Velozo et al., 2020; Tavares et al., 2021). The increase in diameter achieved after preparation with the XPS and an extra 45s of instrumentation, allowed a gutta-percha cone with a larger tip size 40, .04 taper to be fitted, with percentage of voids was $39.25 \%$. In the result obtained significant difference was observed when compared with the PTN (23.28\%), in which four files are used to fit a size 40, .06 taper gutta-percha cone X4. The XPS could be explained due to the increase in time of use of the instrument, consequently producing a larger area prepared, and since XPS does not have a gutta percha cone that corresponds to the diameter and conicity of the preparation. Furthermore, despite the XPS being capable of providing a preparation with a larger volume than that provided by PTN, the adaptation of the cone to the canal walls in group XPS (tip size 40, .04 taper) did not result in a larger conicity than that found in the PTN group (tip size 40, .06 taper). Consequently, the larger volume of the voids occurred in the group of canals prepared with the XPS instruments. This result could be related to the design and MaxWire alloy (Martensite-Austenite Electropolish Flex, FKG) of this instrument that is extremely flexible and irregular, therefore, it shaped a larger diameter in the cervical and middle thirds.

When observing the images obtained in this study, a larger quantity of empty spaces could be perceived in the cervical and middle thirds of the canals prepared, similar findings to those in other study (Iglecias et al., 2017). The single cone technique showed a larger quantity of cement around the gutta percha cone in the flattened areas (Celikten et al., 2016 ; Santos et al., 2020) and lower volume of gutta percha in flattened canals (Schafer et al., 2012). Irrespective of which system - single or multiple file - being used for this preparation, obturation techniques should be studied to reduce the percentage of voids observed for this root canal morphology.

Root canal filling is essential for the long-term success of endodontic treatment (Celikten et al. 2016), and where the three-dimensional obturation procedures of irregular root canals with complex anatomy are concerned, these have been a challenge in endodontic therapy. |Preparation of the root canal is an important factor in adequate filling with gutta percha and cement (Metzger et al 2010). Irrespective of which system - single or multiple file - being used for this preparation, obturation techniques should be studied to reduce the percentage of voids observed for this root canal morphology.

\section{Conclusion}

In conclusion, the canals prepared with XPS system performed with an extra $45 \mathrm{~s}$ of instrumentation, showed a higher volume of voids than those prepared with the PTN system, in obturation of the root canal with the single cone technique in longoval canals of mandibular incisors.

\section{Acknowledgments}

This study was financed in part by the Coordenação de Aperfeiçoamento de Pessoal de Nível Superior - Brasil (CAPES) - Finance Code 001. The authors thank, Department of Morphology, Health Science Center, Federal University of Paraíba (UFPB) for their support. The authors deny any conflicts of interest related to this study.

\section{References}

Celikten, B., Uzuntas, C. F., Orhan, A. I., Orhan, K., Tufenkci, P., Kursun, S., \& Demiralp, K. Ö. (2016). Evaluation of root canal sealer filling quality using a single-cone technique in oval shaped canals: An In vitro Micro-CT study. Scanning, 38(2), 133-140. 
De-Deus, G., Belladonna, F. G., Simões-Carvalho, M., Cavalcante, D. M., Ramalho, C. N. M. J., Souza, E. M., ... \& Silva, E. J. N. L. (2019). Shaping efficiency as a function of time of a new heat-treated instrument. International Endodontic Journal, 52(3), 337-342.

De-Deus, G., Murad, C., Paciornik, S., Reis, C. M., \& Coutinho-Filho, T. (2008). The effect of the canal-filled area on the bacterial leakage of oval-shaped canals. International endodontic journal, 41(3), 183-190.

De-Deus, G., Reis, C., Beznos, D., de Abranches, A. M. G., Coutinho-Filho, T., \& Paciornik, S. (2008). Limited ability of three commonly used thermoplasticized gutta-percha techniques in filling oval-shaped canals. Journal of Endodontics, 34(11), 1401-1405.

Dentsply Sirona. (2017 May 9). ProTaper Next Brochure [Web page]. Retrieved https://www.dentsplysirona.com/content/dam/dentsply/web/Endodontics/globalpagetemplatesassets/downloadpdf\%27s/protapernext/PTN\%20Brochure\%20R OW\%20EN.pdf. Accessed May 01, 2021.

FKG Dentaire. (2021, April 12). Root canal preparations industry data [Web page]. Retroeved from: Available at:https://www.fkg.ch/xpendo/files/FKG_XPendo_Shaper_Finisher_Protocol_Card_EN_FR_DE_WEB_201810.pdf.

Gavini, G., Santos, M. D., Caldeira, C. L., Machado, M. E. D. L., Freire, L. G., Iglecias, E. F., ... \& Candeiro, G. T. D. M. (2018). Nickel-titanium instruments in endodontics: a concise review of the state of the art. Brazilian oral research, 32 (suppl 1), 44-65.

Haapasalo, M., Endal, U., Zandi, H., \& Coil, J. M. (2005). Eradication of endodontic infection by instrumentation and irrigation solutions. Endodontic topics, $10(1), 77-102$.

Heran, J., Khalid, S., Albaaj, F., Tomson, P. L., \& Camilleri, J. (2019). The single cone obturation technique with a modified warm filler. Journal of dentistry, 89, 103181.

Iglecias, E. F., Freire, L. G., de Miranda Candeiro, G. T., Dos Santos, M., Antoniazzi, J. H., \& Gavini, G. (2017). Presence of voids after continuous wave of condensation and single-cone obturation in mandibular molars: a micro-computed tomography analysis. Journal of endodontics, 43(4), 638-642.

Jou, Y. T., Karabucak, B., Levin, J., \& Liu, D. (2004). Endodontic working width: current concepts and techniques. Dental Clinics, 48(1), 323-335.

Keleş, A., Alcin, H., Kamalak, A., \& Versiani, M. A. (2014). Micro-CT evaluation of root filling quality in oval-shaped canals. International endodontic journal, 47(12), 1177-1184.

Keleş, A., \& Keskin, C. (2020). Presence of voids after warm vertical compaction and single-cone obturation in band-shaped isthmuses using micro-computed tomography: A phantom study. Microscopy research and technique, 83(4), 370-374.

Kontakiotis, E. G., Wu, M. K., \& Wesselink, P. R. (1997). Effect of sealer thickness on long-term sealing ability: a 2-year follow-up study. International Endodontic Journal, 30(5), 307-312.

Metzger Z, Zary R, Cohen R, Teperovich E, Paqué F (2010) The quality of root canal preparation and root canal obturation in canals treated with rotary versus self-adjusting files: a three-dimensional micro-computed tomographic study. Journal of Endodontics 36,1569-73.

Mohammadi, Z., \& Abbott, P. V. (2009). The properties and applications of chlorhexidine in endodontics. International endodontic journal, 42(4), 288-302.

Park, E., Shen, Y. A., \& Haapasalo, M. (2012). Irrigation of the apical root canal. Endodontic Topics, 27(1), 54-73.

Pereira, R. D., Brito-Júnior, M., Leoni, G. B., Estrela, C., \& de Sousa-Neto, M. D. (2017). Evaluation of bond strength in single-cone fillings of canals with different cross-sections. International endodontic journal, 50(2), 177-183.

Santos-Junior, A. O., Tanomaru-Filho, M., Pinto, J. C., Tavares, K. I. M. C., Pivoto-João, M. M. B., \& Guerreiro-Tanomaru, J. M. (2020). New Ultrasonic Tip Decreases Uninstrumented Surface and Debris in Flattened Canals: A Micro-computed Tomographic Study. Journal of Endodontics, $46(11), 1712-1718$.

Schäfer, E., Nelius, B., \& Bürklein, S. (2012). A comparative evaluation of gutta-percha filled areas in curved root canals obturated with different techniques. Clinical oral investigations, 16(1), 225-230.

Somma, F., Cretella, G., Carotenuto, M., Pecci, R., Bedini, R., De Biasi, M., \& Angerame, D. (2011). Quality of thermoplasticized and single point root fillings assessed by micro-computed tomography. International endodontic journal, 44(4), 362-369.

Sundqvist, G., \& Figdor, D. (1998). Endodontic treatment of apical periodontitis. Essential endodontology, $242-269$.

Tavares, K. I., Pinto, J. C., Santos-Junior, A. O., Torres, F. F., Guerreiro-Tanomaru, J. M., \& Tanomaru-Filho, M. (2021). Micro-CT evaluation of filling of flattened root canals using a new premixed ready-to-use calcium silicate sealer by single-cone technique. Microscopy Research and Technique, 84(5), 976-981.

Velozo, C., Silva, S., Almeida, A., Romeiro, K., Vieira, B., Dantas, H., ... \& De Albuquerque, D. S. (2020). Shaping ability of XP-endo Shaper and ProTaper Next in long oval-shaped canals: a micro-computed tomography study. International Endodontic Journal, 53(7), 998-1006.

Versiani, M. A., Pécora, J. D., \& Sousa-Neto, M. D. (2013). Microcomputed tomography analysis of the root canal morphology of single-rooted mandibular canines. International Endodontic Journal, 46(9), 800-807.

Wang, Y., Liu, S., \& Dong, Y. (2018). In vitro study of dentinal tubule penetration and filling quality of bioceramic sealer. PLoS One, $13(2)$, e0192248.

Wu, M. K., Fan, B., \& Wesselink, P. R. (2000). Diminished leakage along root canals filled with gutta-percha without sealer over time: a laboratory study. International Endodontic Journal, 33(2), 121-125. 